\title{
EVALUATING INDOOR AIR QUALITY IAQ IN PRIMARY SCHOOLS IN DOWNTOWN CAIRO, EGYPT
}

\author{
Nourhan A. Sary Eldin ${ }^{1 *}$, Ahmed A. Faggal ${ }^{2}$ and Tamir El-Khouly ${ }^{3}$ \\ + 1,2,3 Department of Architecture, Faculty of Engineering, Ain Shams University, Egypt
}

1,3 Department of Architecture, School of Sciences and Engineering, The American University in Cairo, Egypt

2, Department of Architecture, Faculty of Engineering, Canadian International College, Egypt

*Corresponding Author E-mail: nourhansaryeldin@ aucegypt.edu

Received :5 Sept. 2021 Accepted:14 Oct. 2021

\begin{abstract}
There has been a growing interest in investigating indoor air quality levels in complex buildings such as primary schools to assess the impact of students' performance and well-being. Concerns are raised towards identifying the parameters that negatively affect indoor air quality in classrooms. Poor indoor air quality is expected to play a vital role in the prevalence of allergic and respiratory diseases.

Indoor air quality in schools plays an important role in assessing student exposure to air pollution as children are more sensitive when exposed to unhealthy air because they breathe more air than their body weight and at a faster rate.

This study shows measurements of carbon dioxide (CO2), particulate matter (PM2.5) and volatile organic compounds (VOCs) on indoor air quality for classrooms in a primary school in Cairo, Egypt, and discusses the concentration levels of these parameters on indoor air quality. Readings of the measurements were applied on an air quality monitoring system that is developed by the authors. This study raises awareness towards considering indoor air quality in schools designs with the purpose to minimize health risks and improve students' Learning performance.
\end{abstract}

KEYWORDS: Indoor air quality, primary school, natural ventilation, carbon dioxide (CO2), particulate matters (PM2.5), volatile organic compounds (VOCs).

$$
\begin{aligned}
& \text { تقييم جودة الهو اء الداخلي بالمدارس الإبتدائية بوسط القاهرة، مصر } \\
& \text { نور هان سري الدين1*، أحمد عاطف فجال2، تامر عبد العظيم الخولي3 } \\
& \text { 1,2,3 قسم الهندسة المعمارية، كلية الهندسة، جامعة عين شمس، القاهرة، مصر } \\
& \text { 1,3 قسم الهندسة المعمارية، كلية العلوم و الهندسة، الجامعة الامريكية، القاهرة، مصر } \\
& 2 \text { قسم الهندسة المعمارية، كلية الهندسة، الكلية الكندية الدوليه ،القاهرة، مص }
\end{aligned}
$$




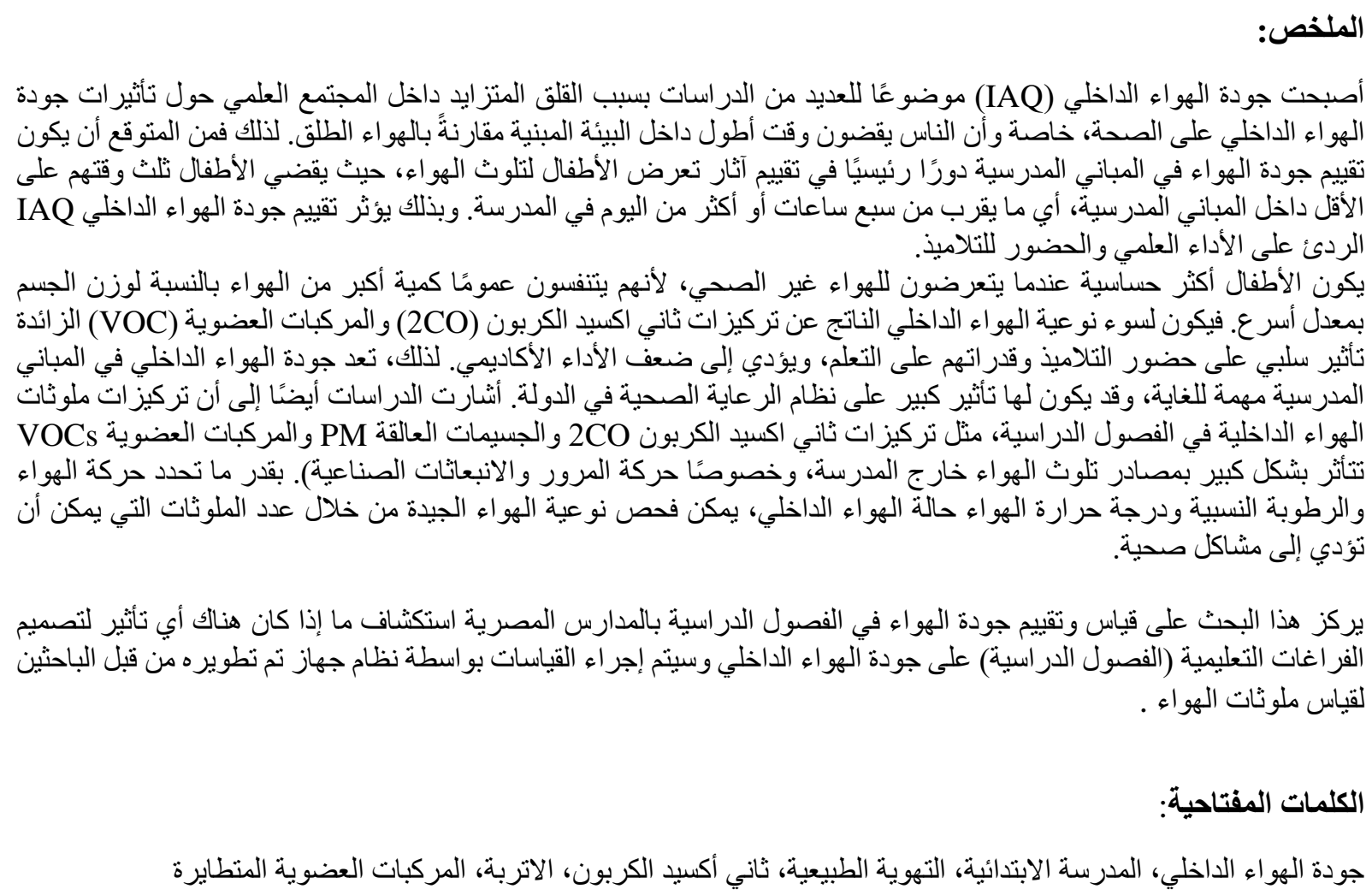

\section{INTRODUCTION}

In recent years, the world has been suffering from serious air pollution problems with the growing industrial and urbanization and increasing energy consumption in industrialized cities. Studies have shown that most cities all over the world do not meet the World Health Organization (WHO) air quality guidelines for acceptable air quality [1]. The map highlights areas within countries that exceed WHO air quality limits is shown in Figure 1. Air pollution can lead to health damage to public health, including the health of 'sensitive' populations such as children, pregnant, asthmatics, and the elderly. WHO statistics show in $2016,91 \%$ of the world population was living in places where the WHO air quality guidelines levels were not met. Ambient (outdoor air pollution) in both cities and rural areas were estimated to cause 4.2 million premature deaths worldwide in 2016 [2]. Health symptoms like stroke, heart disease, lung cancer, and respiratory diseases including asthma are known to be associated with air quality.

In recent years, the concern about the effect of air pollution on children has been raised. Children are more sensitive when they are exposed to unhealthy air because they generally breathe a higher volume of air relative to body weight at a faster rate. Therefore, indoor air quality in school buildings is highly important, and may have a significant impact on a nation's healthcare system. Children spend at least a third of their time inside school buildings, that is, approximately seven or more hours a day in school. Poor IAQ can affect scholarly performance and attendance. The authors in [3] investigated that there is a statistically significant association between IAQ, and health associated with the prevalence of allergic and respiratory diseases among school children with poor IAQ in classrooms. A study carried out in Greece showed that poor indoor air quality has a negative impact on students' achieved scores and caused lowest attendance rates [4]. 
Over the past decades, Egypt has been experiencing serious air pollution problems due to rapid industrialization, urbanization, and increasing energy consumption [5]. A study from WHO shows that air pollution in Egypt, especially in Cairo and Alexandria, has been of concern for several years. Particulate matter is the most common air pollutant in urban and industrial areas [6]. The few epidemiological studies of air pollution in Egypt have indicated a significant increase in chest problems for those exposed to high levels of particulate in the residential industrial areas. Furthermore, particulate matter and lead pollution have been recognized as the most deleterious agents to health in Cairo's environment [7].

According to IQAir (IQAir is a Swiss air quality technology company, specializing in protection against airborne pollutants, developing air quality monitoring and air cleaning products. IQAir also operates AirVisual, a real-time air quality information platform.) Most polluted cities (PM2.5) 2019 annual report Cairo came at 1026 place according to data aggregated over 60.000 data points and Egypt came at 56 according to data aggregated over 89 data points [8]. IQAir ranking is shown in Figure 2.

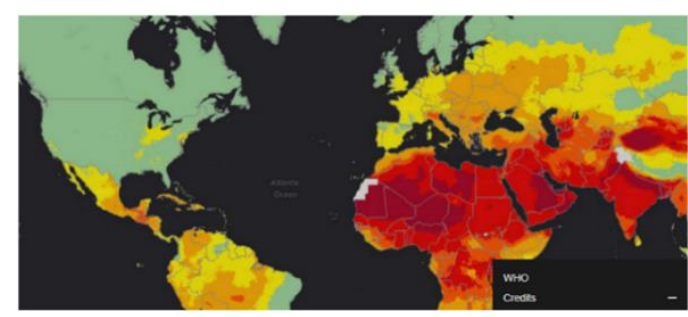

Fig. 1: interactive maps highlight areas within countries that exceed WHO air quality limits [1].

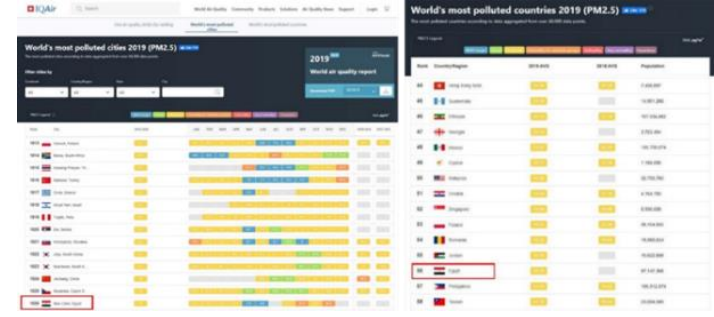

Fig. 2: (left) World most polluted cities 2019 (PM2.5), (right) World most polluted countries 2019 (PM2.5) [7].

\section{AIR POLLUTANTS}

The most common pollutants that will be measured are particulate matter $(\mathrm{PM})$, carbon dioxide $\left(\mathrm{CO}_{2}\right)$, volatile organic compounds (VOCs) and meteorological data such as relative humidity (RH) and temperature will also be measured.

Carbon dioxide $\mathrm{CO}_{2}$ is a colorless gas having a faint sharp odor and a sour taste. It is one of the most important greenhouse gases linked to global warming [9]. $\mathrm{CO}_{2}$ is primarily a by-product of human metabolism and is constantly being emitted into the indoor environment by building occupants. $\mathrm{CO}_{2}$ may come from combustion sources as well. The major sources of indoor carbon dioxide are as follows: People, kerosene and gas space heaters, tobacco smoke, and outside air [10].

Particulate matters PM, known as dust, is a mixture of organic and inorganic substances found in the air. Some particles, such as dust, dirt, soot, or smoke, are large or dark enough to be seen with the naked eye. Others are so small they can only be detected using an electron microscope. Respiratory health problems can be caused by both PM10 (PM with a size 10 micrometers and smaller) and PM2.5 (PM with a size 2.5 micrometers and smaller). PM2.5 are finer particles that travel deeper into the lungs and settle there. Elderly and young children and the elderly are more susceptible to the health effects of PM2.5. PM2.5 Negatively affects the lung and aggravates asthma and heart disease [11].

Volatile organic compounds (VOCs) are emitted as gases from certain solids or liquids. VOCs include a variety of chemicals, some of which may have short- and long-term adverse health effects. 
Concentrations of many VOCs are consistently higher indoors (up to ten times higher) than outdoors. VOCs are emitted by a wide array of products numbering in the thousands. Examples include paints and lacquers, paint strippers, cleaning supplies, pesticides, building materials and furnishings, office equipment such as copiers and printers, correction fluids and carbonless copy paper, graphics and craft materials including glues and adhesives, permanent markers, and photographic solutions [12].

\section{TYPOLOGIES of SCHOOLS}

Schools in Egypt have various architectural configurations which have an impact on the indoor environmental quality. The configurations divide into three typologies: Linear type single or double loaded, clustered, and central around court. Table 1 shows the three typologies.

This research studies the linear type single and double loaded and the clustered type

Table 1: schools design configurations- Source: Authors

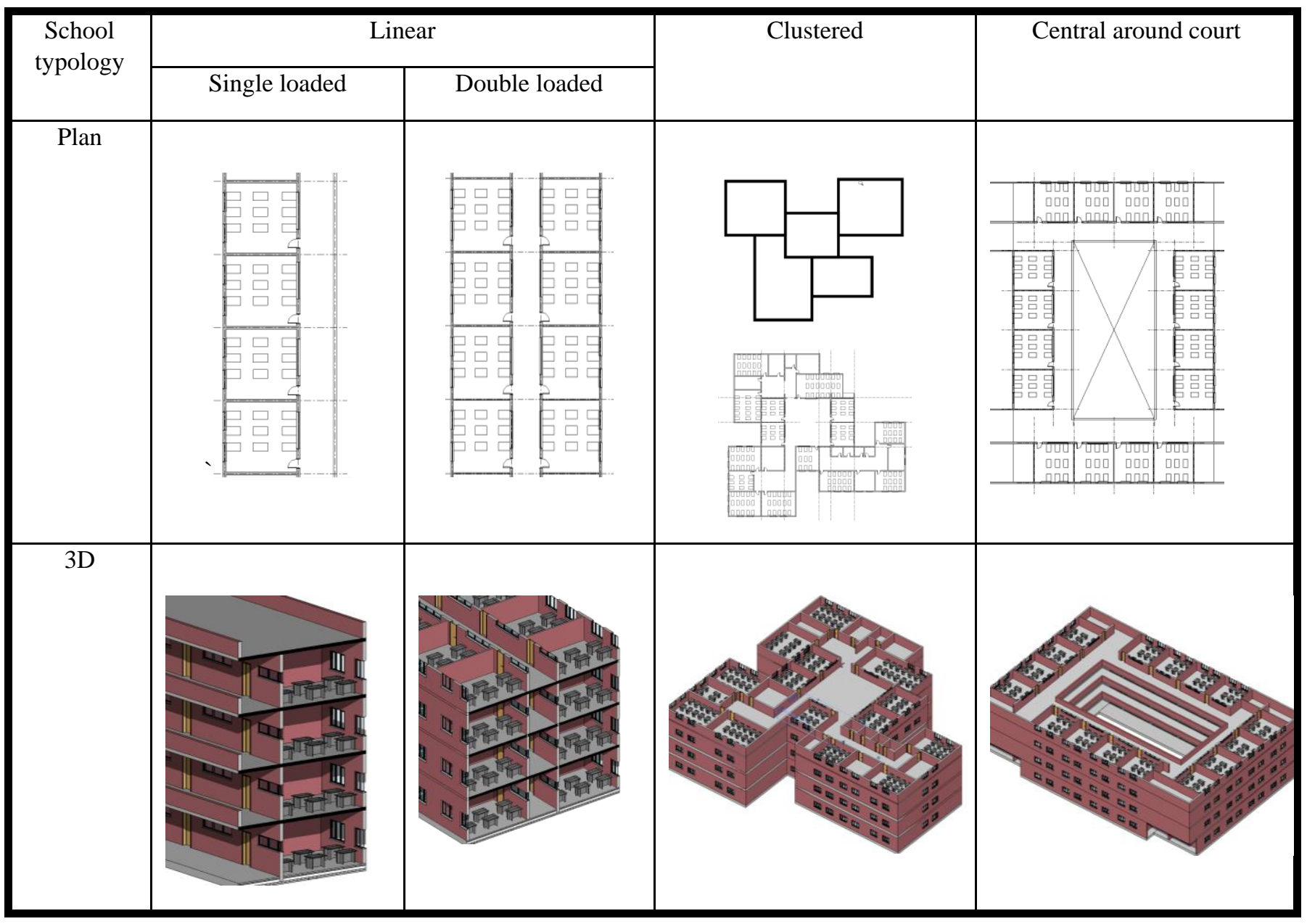




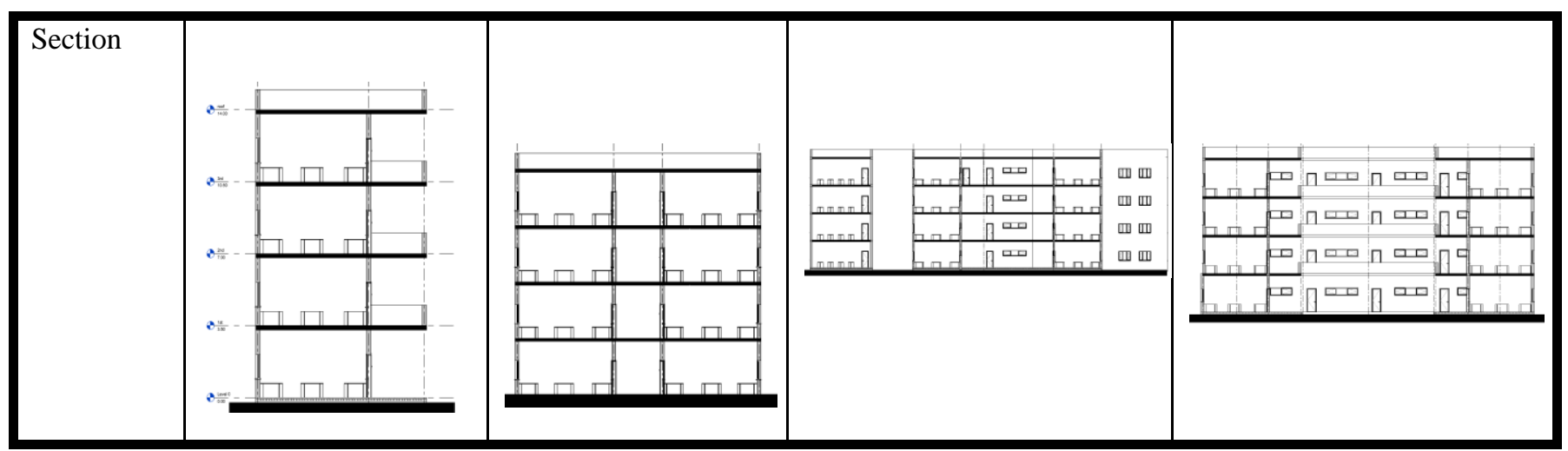

\section{RESEARCH METHOD}

\subsection{A new Indoor Air Quality Monitoring Device}

The devices available in the Egyptian Environmental Affairs Agency (EEAA) monitor air pollutants in external spaces only and do not measure indoor spaces, and each device measures only one factor; one device measures PM2.5, another measures $\mathrm{CO} 2$, Temperature and Humidity, and a third measures $\mathrm{CO}_{2}$ and VOC.

As there is no available device that can monitor all the parameters that are required for this study and because of the difficulty of placing three devices in the classroom to monitor air quality parameters, the researchers prepared and developed a new device using the Arduino platform and recorded the readings on the computer for comparison.

Based on this, the new device achieves the following purposes: firstly, it measures air quality in the classroom, and secondly, it contains multiple sensors to simultaneously read and record factors responsible for air quality. The Arduino platform uses three sensors that monitor five types of air quality parameters: PM2.5, CO2, VOCs, temperature and humidity.

\subsubsection{The Calibration Process}

In order to validate the use of this new device, it has been calibrated contrasting its readings against three authorised and validated devices by the EEAA; Aeroqual portable (series 500) measuring $\mathrm{CO}_{2}$ and VOC, AQ9600 measuring Particulate matters PM2.5, and CO2390 measuring $\mathrm{CO}_{2}$, Temperature and Humidity.

The calibration process extended to eight as a reasonable time frame to monitor, detect and record the results under different conditions. After completion, it was found that the error factor in reading $\mathrm{CO}_{2}$ and VOC is 0.05 , while in reading PM2.5 is 0.01 . The error factors are minimal but all the reading values that are used in this study have been corrected according to these error factors. Hence, the device became validated for use. Figure. 3 shows the framework and illustration of the developed monitoring device.
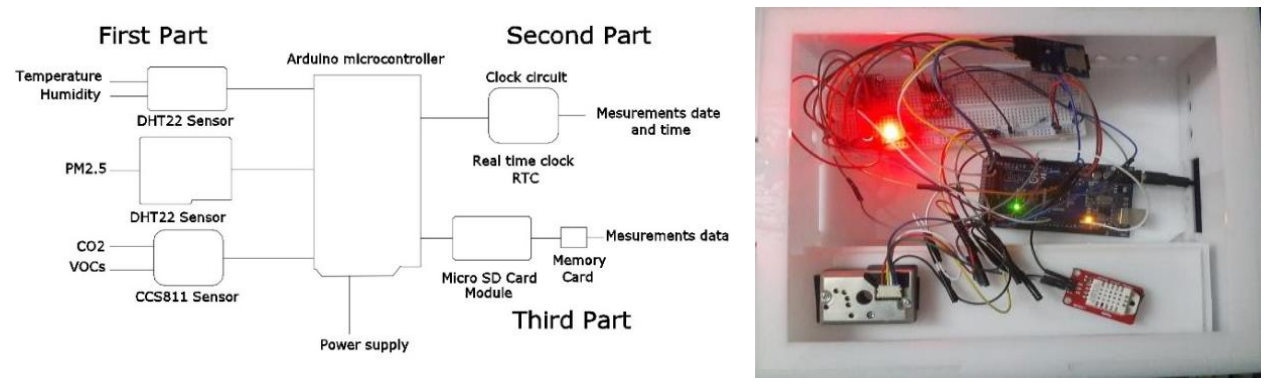

Fig. 3: The air quality monitoring framework Source: Authors 
The framework of this device supports user-friendly objectives for monitoring the parameters and understanding the conditions under which air quality levels in classrooms can be affected. Since it includes multiple types of sensors, the device can be customised to detect some other various conditions, e.g., rain detection by using rain sensor module [13].

\subsubsection{Advantages and Disadvantages}

The advantages of this device are:

1. It is a mobile device that can be remotely located anywhere.

2. It is an integration of multiple parameters into one digital platform.

The disadvantage:

1. The results come in the form of numeric values that requires the researcher to transform data into a graph to be easily read.

This framework collects of environmental parameters, e.g., $\mathrm{CO}_{2}$ concentrations and the amount of dust PM2.5 present in the air which is an important indicator of air quality.

The monitoring device is located $150 \mathrm{~cm}$ above the floor.

The measurements were made between October 18, 2020, and December 10, 2020.

\subsection{Sampling Selection Criteria and Data Collection}

A field study was conducted on five classrooms in four primary schools located in different residential areas, where the students' ages range from six to ten years. The sampled classrooms are representative of many cases that can be found in other schools across Egypt. The measurements were taken in hot and cold seasons. The selected schools are in Misr El Qadima district, in the southern urban area of Greater Cairo within the boundaries of Cairo Governorate Figure. 3. Field visits were conducted to the selected schools to obtain their consent to participate in the study.

Schools were chosen carefully to be different in the architectural design configuration of school buildings but share the same climate conditions, so these schools to some extents are in the same geographical zone. To make the climate a fixed factor to measure the varies school designs.

The sample of schools selected to participate in this study provided the researchers with the actual drawings of the school building after its construction (as-built set of drawings). In fact, after the COVID19 pandemic, it was difficult to obtain permission from school principals to run the experiments and many schools refused to participate and withdrew from the study. But the schools that allowed the study to take place were assured that the data would only be used for scientific purposes. The observed results show the need to take indoor air quality monitoring seriously in primary schools in Egypt in general. As a result of the measurement time limitations provided by the schools due to COVID-19 precautionary measures, the results are a close representation of the general conditions in the classroom studied but further measurements are recommended. Measurements over a long period were conducted to assure more reliability. All schools' teaching duration operated in a naturally ventilated environment and all buildings are in a good condition. Classroom cleaning work took place after students left school or 
before they arrived around 7:00 AM. The measurements were taken between October and December 2020 in the presence of students.

Table 4: cold area measurements - Source: Authors

\begin{tabular}{|c|c|c|c|c|}
\hline School & A & B & $\mathrm{C}$ & $\mathrm{D}$ \\
\hline $\begin{array}{l}\text { School } \\
\text { Name }\end{array}$ & $\begin{array}{l}\text { Salah Eldin } \\
\text { primary school }\end{array}$ & $\begin{array}{l}\text { Field } \\
\text { Marshal } \\
\text { Ahmed } \\
\text { Ismail } \\
\text { Official } \\
\text { Languag } \\
\text { e School }\end{array}$ & $\begin{array}{l}\text { Future } \\
\text { language } \\
\text { school }\end{array}$ & $\begin{array}{l}\text { Ahmed Lotfy El } \\
\text { Sayed Primary } \\
\text { School }\end{array}$ \\
\hline $\begin{array}{l}\text { Loctatio } \\
\mathrm{n}\end{array}$ & $\begin{array}{l}\text { Elzaharaa -Misr el } \\
\text { Qadima }\end{array}$ & $\begin{array}{l}\text { Elzahara } \\
\text { a -Misr el } \\
\text { Qadima }\end{array}$ & $\begin{array}{l}\text { Al Fostat - } \\
\text { Misr el } \\
\text { Qadima }\end{array}$ & $\begin{array}{l}\text { AlManial -Misr el } \\
\text { Qadima }\end{array}$ \\
\hline $\begin{array}{l}\text { Year of } \\
\text { construct } \\
\text { ion }\end{array}$ & 1990 & 2000 & 2010 & 1995 \\
\hline $\begin{array}{l}\text { Design } \\
\text { configura } \\
\text { tion }\end{array}$ & Cluster & $\begin{array}{l}\text { L-shape } \\
\text { building }\end{array}$ & $\begin{array}{l}3 \text { linear } \\
\text { buildings } \\
\text { parallel to } \\
\text { each other }\end{array}$ & $\begin{array}{l}\text { Two buildings are } \\
\text { opposite to each } \\
\text { other. }\end{array}$ \\
\hline & $-3-1=$ & 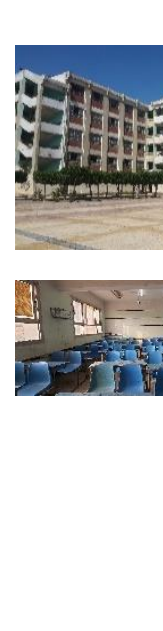 & 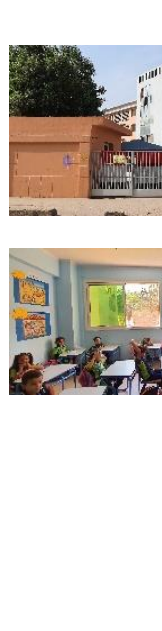 & $\begin{array}{l}65 \\
45 \\
4 \\
4\end{array}$ \\
\hline
\end{tabular}




\begin{tabular}{|c|c|c|c|c|}
\hline $\begin{array}{l}\text { Number } \\
\text { of stories }\end{array}$ & $\begin{array}{l}\text { four-story (ground } \\
\text { and } 3 \text { typical } \\
\text { floors). }\end{array}$ & $\begin{array}{l}\text { four- } \\
\text { story } \\
\text { (ground } \\
\text { and } 3 \\
\text { typical } \\
\text { floors). }\end{array}$ & $\begin{array}{l}\text { four-story } \\
\text { (ground and } \\
3 \text { typical } \\
\text { floors). }\end{array}$ & $\begin{array}{l}\text { four-story (ground } \\
\text { and } 3 \text { typical } \\
\text { floors). }\end{array}$ \\
\hline $\begin{array}{l}\text { No. of } \\
\text { students }\end{array}$ & 520 & 1650 & 1400 & 430 \\
\hline $\begin{array}{l}\text { Type and } \\
\text { Age }\end{array}$ & $\begin{array}{l}\text { public primary } \\
\text { school } \\
\text { students' age six } \\
\text { to twelve years }\end{array}$ & $\begin{array}{l}\text { public } \\
\text { primary } \\
\text { school } \\
\text { students' } \\
\text { age five } \\
\text { to } \\
\text { eighteen } \\
\text { years }\end{array}$ & $\begin{array}{l}\text { a private } \\
\text { school for } \\
\text { students' age } \\
\text { five to } \\
\text { eighteen } \\
\text { years }\end{array}$ & $\begin{array}{l}\text { public primary } \\
\text { school } \\
\text { students' age } \\
\text { between six and } \\
\text { twelve years }\end{array}$ \\
\hline
\end{tabular}

to take place were assured that the data would only be used for scientific purposes. The observed results show the need to take indoor air quality monitoring seriously in primary schools in Egypt in general. As a result of the measurement time limitations provided by the schools due to COVID-19 precautionary measures, the results are a close representation of the general conditions in the classroom studied but further measurements are recommended. Measurements over a long period were conducted to assure more reliability. All schools' teaching duration operated in a naturally ventilated environment and all buildings are in a good condition. Classroom cleaning work took place after students left school or before they arrived around 7:00 AM. The measurements were taken between October and December 2020 in the presence of students.

\section{School A}

This is a public primary school for students' age six to twelve years (Grades 1-6). Around 520 students are registered in this school. The school is a four-floor building (a ground floor and three typical floors). Classes start at 8:00 am and end at 12:30 pm. Two classrooms were chosen in this school located on the second floor; one is oriented towards South while the other is oriented towards the North. There are two schools, one club and one mosque in the same school district. Break time is from 10:25 am to 10:50 am.

\section{School B}

This is a public primary school for students' ages five to eighteen years (Grades 1:12). Around 1650 students are registered in this school. The school is a four-story (ground and 3 typical floors). Classes start at 8:00 am and end at 1:15 pm. The selected classroom is on the second floor and oriented towards the South. The school is in a highly polluted area due to a chemical factory. There are three schools attached to the selected school.

\section{School C}

This is a private school for students' ages five to eighteen years (Grades 1:12). Around 1400 students are registered in this school. The school building is of four-story (ground and 3 typical floors). The 
classes start by 8:00 am and end by 2:00 pm. The selected classroom is located on the ground floor and oriented towards the North. There are four schools and one big mosque in the same school district.

\section{School D}

It is a public primary school which provides education for students' ages between six and twelve years (Grades 1-6). Around 430 students were studying in this school. The school is a four-story (ground and 3 typical floors). The selected classroom is located on the ground floor and oriented towards the North. There are three schools and a club in the same school district. The Nile River is located on the eastern side of the school.

\subsection{Characteristics of the selected classrooms}

\section{Classroom School A (SA-C1)}

The classroom volume is around $100 \mathrm{~m} 3$ (height $3 \mathrm{~m}$, width $6 \mathrm{~m}$, length $5.5 \mathrm{~m}$ ). The classroom has two wall mounted fans as shown in Figure. 5. The windows are in two walls that face South and East directions. Class capacity is 19 occupants: 18 students and one teacher. The classroom is located on the last floor and is oriented towards the South.

\section{Classroom School A (SA-C2)}

The classroom volume is around $100 \mathrm{~m} 3$ (height $3 \mathrm{~m}$, width $6 \mathrm{~m}$, length $5.5 \mathrm{~m}$. The classroom has two wall mounted fans as shown in Figure. 6. The windows are on two sides facing West and North. The classroom is on the first floor. There are 21 students in the classroom.

\section{Classroom School B (SB-C3)}

The classroom volume is around $93.75 \mathrm{~m} 3$ (height $=3 \mathrm{~m}$, width $=6.25 \mathrm{~m}$, length $=5 \mathrm{~m}$ ). The classroom has two ceiling fans as shown in Figure 7. The windows are on two opposite sides, at the southern-east direction and the other window is located at the corridor but is closed during the measurements time. The classroom is located on the second floor. There are 20 students in the classroom. There is no handmade works mounted in the classroom during the measuring time. The classroom is usually cleaned at 7:15 am before the arrival of the students. Dust was observed on indoor surfaces of the classroom. A chemical factory located close to the studied classroom is supposed to be a source of pollutants.

\section{Classroom School C (SC-C4)}

The building and other facilities were in a very good condition. The classroom is on the ground floor. The classrooms were cleaned after the students' departure at 2:00 $\mathrm{pm}$. The classroom volume is around $120.5 \mathrm{~m} 3$ (height $=3 \mathrm{~m}$, width $=6 \mathrm{~m}$, length $=6.7 \mathrm{~m}$ ). The classroom has one ceiling fan as shown in Figure. 8 . The classroom is in the north direction of the building. The windows are on two opposite sides as shown in figure 8 , at the north direction and the other window located at the corridor but it was closed during the measurements time.

\section{Classroom School D (SD-C5)}

The building and other facilities were in a good condition. The classroom is on the first floor. The classroom was cleaned at 7:30am. The classroom volume is around $120 \mathrm{~m} 3$ (height $=3 \mathrm{~m}$, width $=5 \mathrm{~m}$, length $=8 \mathrm{~m}$ ). The classroom has two ceiling fans as shown in Fig. 12. The classroom is in the north direction of the building. The windows are on two opposite sides, at the north direction and the other window located at the corridor. Walls were covered by students' handmade works during the measuring time as shown in Figure 9. 


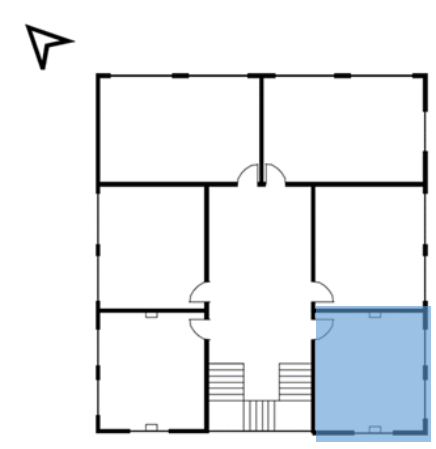

Fig. 5: School A (SA-C1)

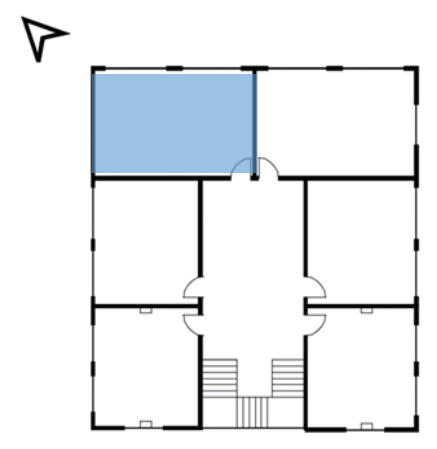

Fig. 6: School A (SA-C2)

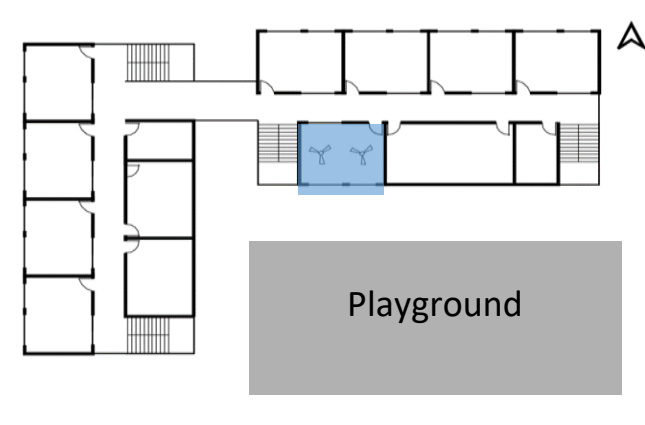

Fig. 7: School B (SB-C3)

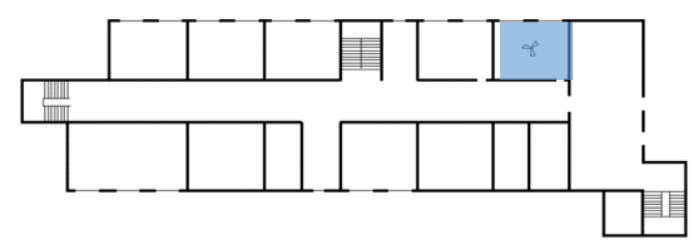

Fig. 8: School C (SC-C4)
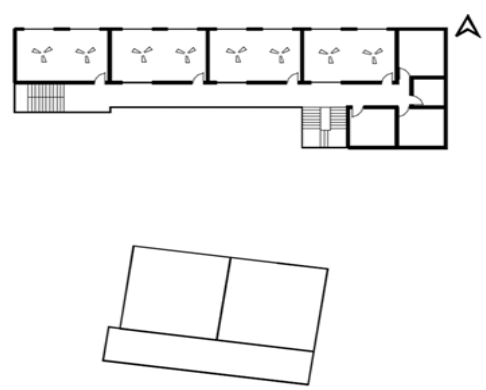

Fig. 5: School A (SA-C1)

\section{AIR POLLUTANTS}

Tables 2 and 3 show the average values of the three parameters that were measured for the five classrooms during a school day from 8:00 AM to 14:00 PM, where the sample was measured for classrooms located in qualitatively cold and mild areas.

\subsection{Carbon Dioxide $\left(\mathrm{CO}_{2}\right)$ levels inside classrooms}

Figure 9,10. shows a comparison of $\mathrm{CO} 2$ concentration levels for the five natural ventilated classrooms in both mild and cold areas during full student occupancy. By comparing these results with the values recommended by the World Health Organization; WHO standard, regarding CO2 concentration levels 
(1300 ppm) and ASHRAE guidelines and ventilation rates $(7.5 \mathrm{~L} / \mathrm{sec} /$ person) in classrooms, $\mathrm{CO} 2$ concentration levels within these classrooms are not consistent with WHO and ASHRAE Standard 62 recommendations.

It is also noted that when the classroom is empty during break time, $\mathrm{CO} 2$ levels decrease; the classroom was open at the time of the measurement, but it still exceeded the universally accepted limits.

After the break time, the reading shows a marked increase in $\mathrm{CO} 2$ concentrations; the maximum levels of carbon dioxide in the autumn temperate season were about 8000 parts per million, while it did not exceed 6000 parts per million during the cold winter season.

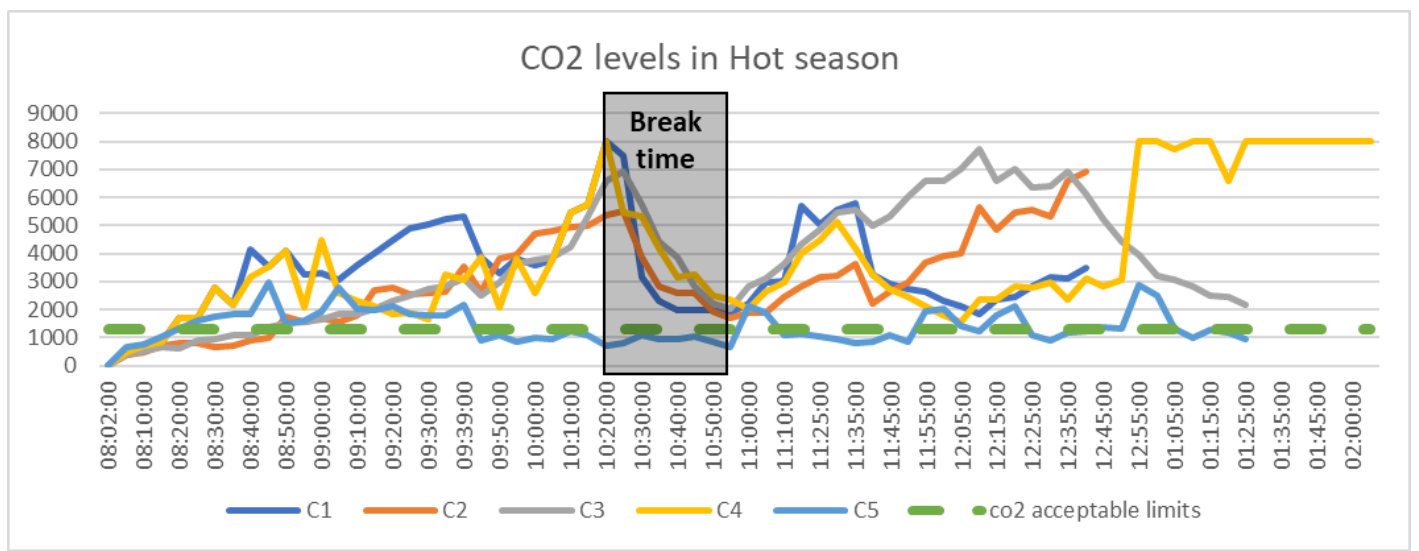

Fig. 9: $\mathrm{CO} 2$ concentrations in classrooms (mild areas) - Source: Author

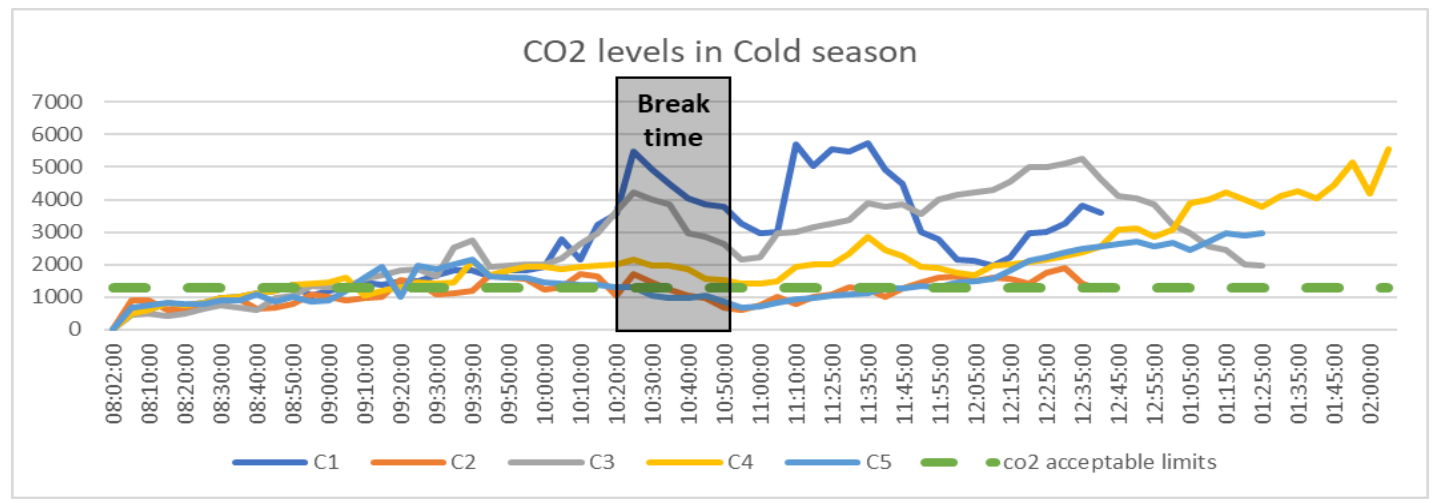

Fig. 10: $\mathrm{CO} 2$ concentrations in classrooms (cold areas) - Source: Authors

\subsection{Volatile Organic Compounds (VOC) levels inside classrooms}

Concentration levels of VOCs exceed accepted global standards during the measurement time in both temperate (autumn) and (winter) seasons as shown in the attached graph of Figure 11,12.

Break time levels decrease in concentrations, but they gradually rise again after students return from their break. These levels are higher than the levels recommended by the World Health Organization and ASHRAE guidelines. It is noted that the concentration levels in the mild season (autumn) are higher than the levels of the cold season measurements (winter); where the maximum levels of VOCs in the temperate season are approximately $1200 \mathrm{ppm}$ while they do not exceed 1,000 ppm during the cold 
season as shown in the Figure 11,12. Classrooms with students' handiwork that are hung on walls record higher readings in concentration levels than others that do not have any educational materials mounted on the walls. Student personal possessions, bags, etc. may contribute to the effect on the measured levels of VOCs.

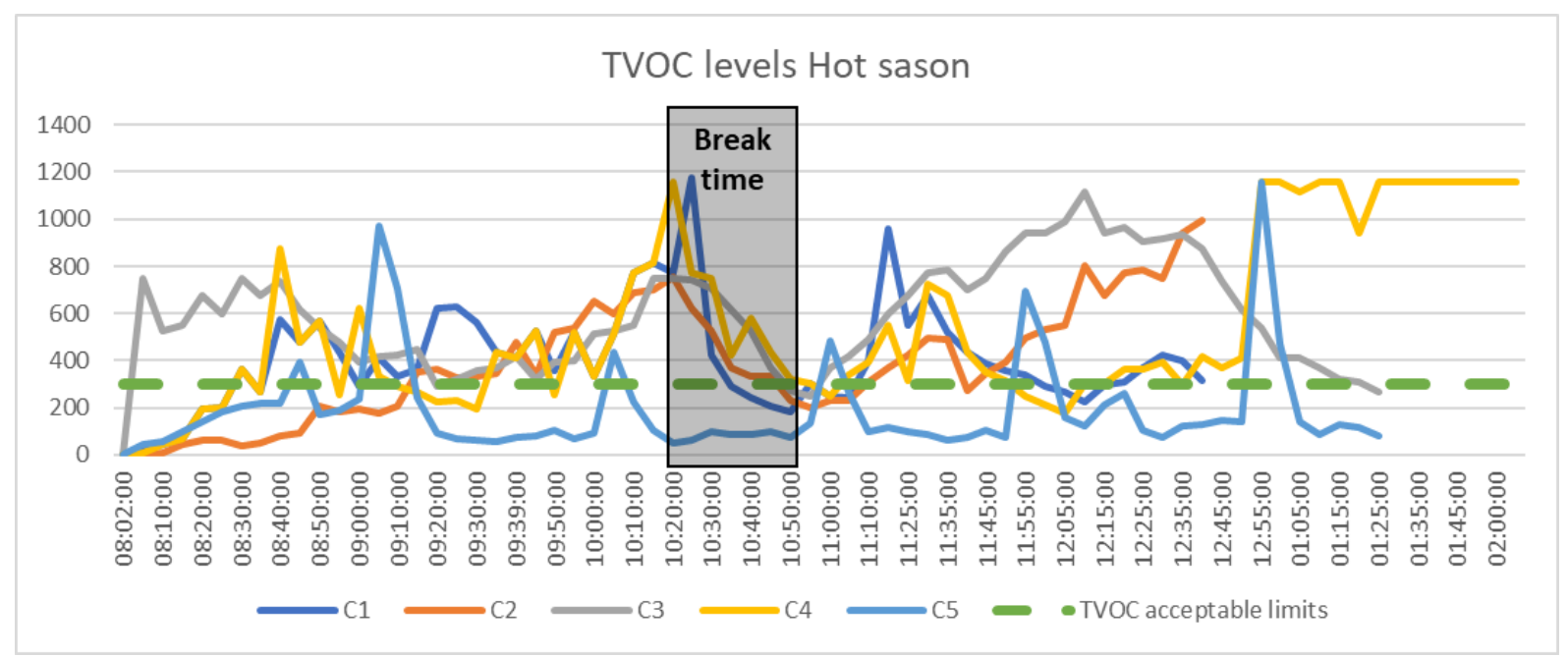

Fig. 11: TVOC concentrations in classrooms (mild areas) - Source: Authors

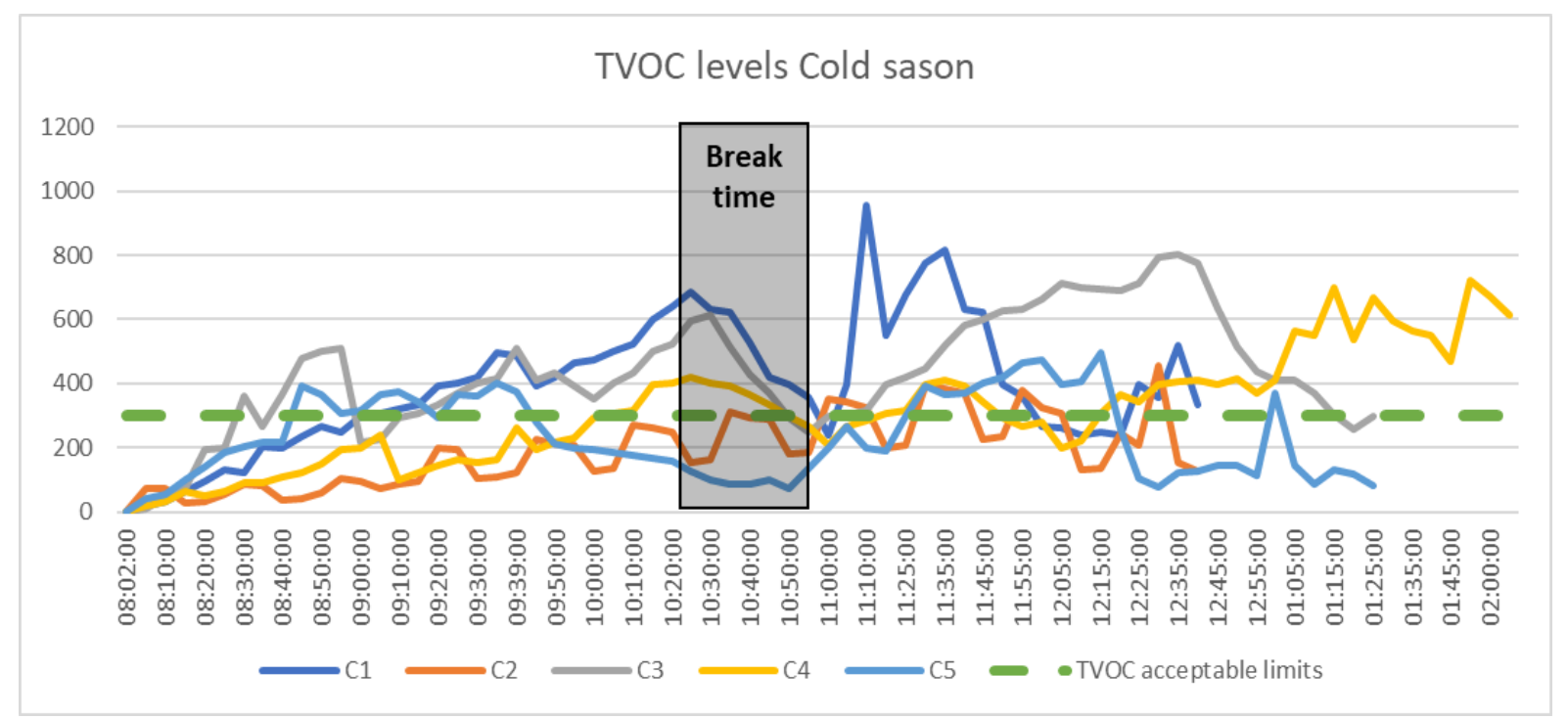

Fig. 12: TVOC concentrations in classrooms (cold areas) - Source: Authors

\subsection{Particulate matters (PM2.5) levels inside classrooms}

The comparison between the PM2.5 concentration level for the 5 classrooms during the natural ventilation mode in both hot and cold seasons is shown in Figure 13,14. It is observed that the dust PM2.5 levels have fluctuated, and it is above the acceptable limits. Morning activities (both outdoor and indoor) influenced indoor TPM concentration. The outdoor air may also have contributed to this value 
as the windows were fully opened during this period. The classrooms that had been cleaned with detergent before 7:30 am have high concentration levels during the early hours.

In general, the elevated indoor concentration of TPM is due to polluted outdoor air. Desert climate of this country also needs to be taken into consideration.

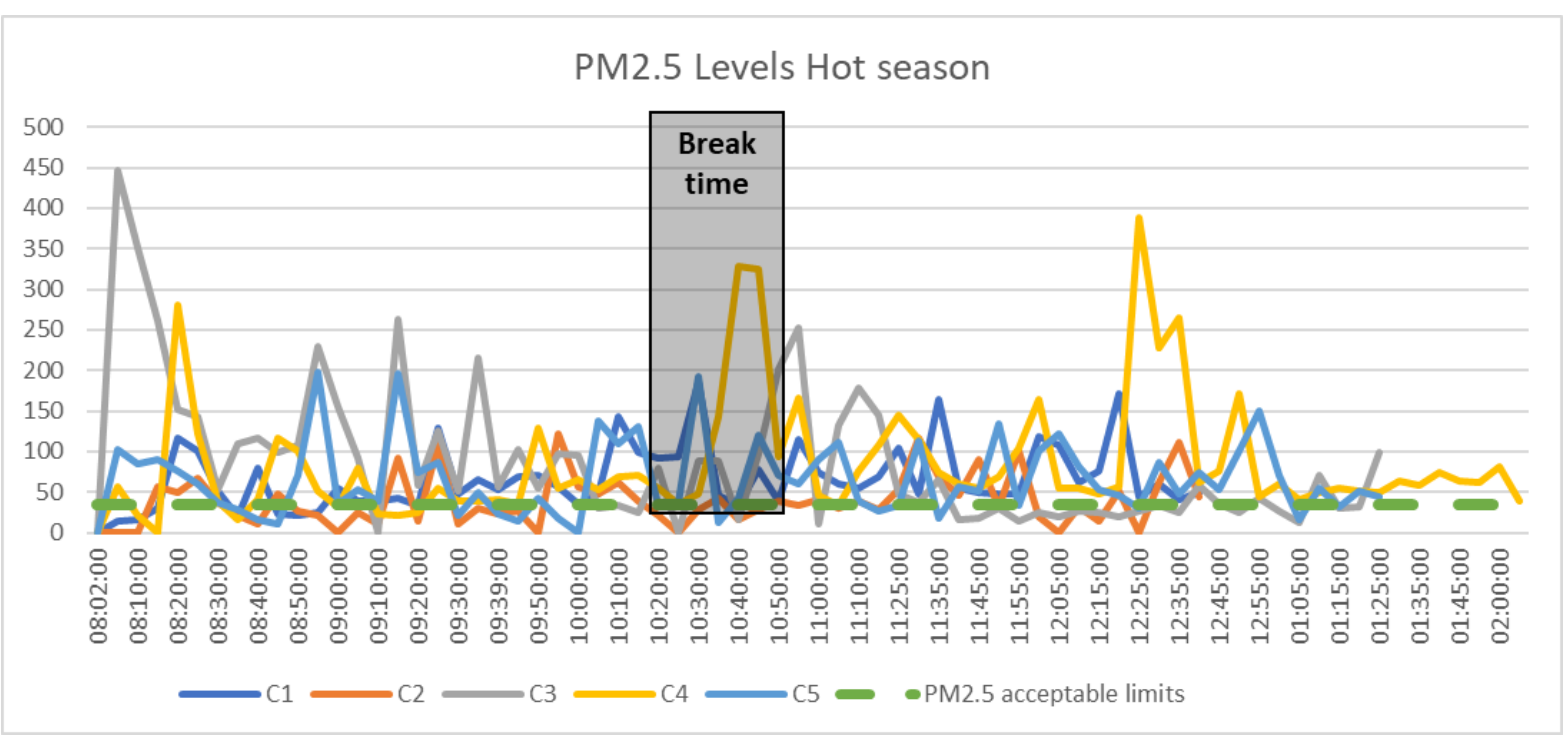

Fig. 13: PM2.5 concentrations in classrooms (mild areas) - Source: Authors

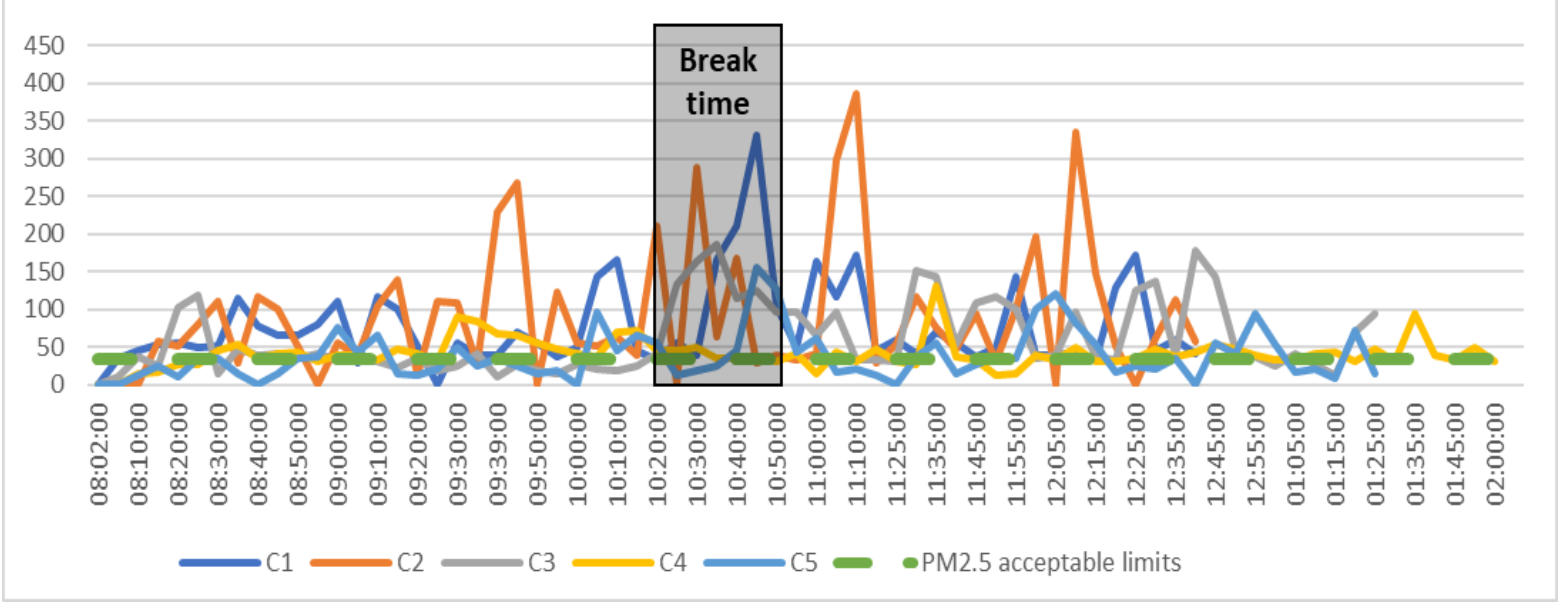

Fig. 14: PM2.5 concentrations in classrooms (cold areas) - Source: Authors

\subsection{Temperature and Humidity levels inside classrooms}

It is noted that the levels of temperature and humidity readings are higher than the universally accepted standards in the measurement times (autumn and winter); see Figure 15,16 

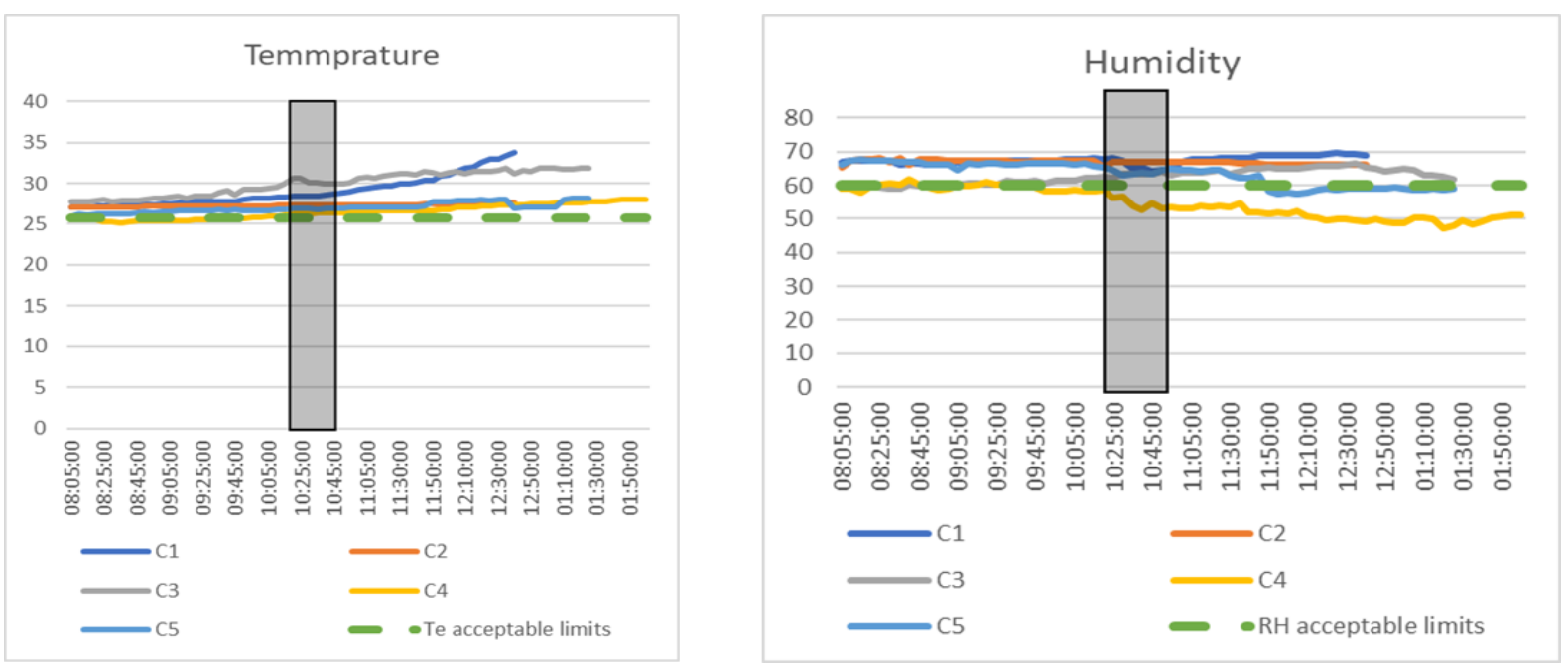

Fig. 15: Temperature and humidity levels (mild areas) - Source: Authors
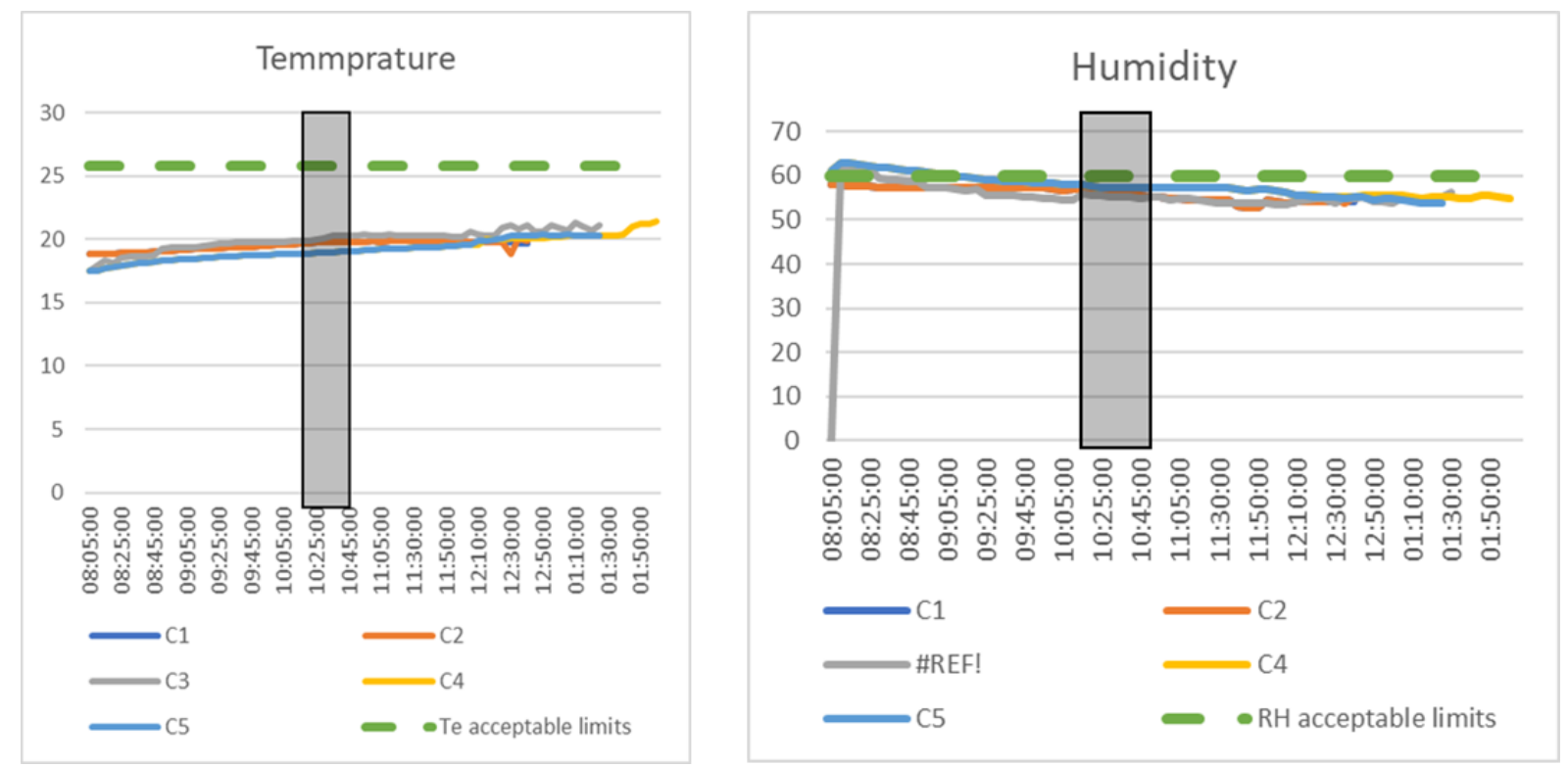

Fig. 16: Temperature and humidity levels (cold areas) - Source: Authors 
Table 2: mild area measurements - Source: Authors

\begin{tabular}{|c|c|c|c|c|c|c|c|c|c|c|}
\hline \multirow[b]{2}{*}{$\begin{array}{l}\tilde{\curvearrowright} \\
\frac{\Omega}{\delta} \\
\frac{\delta}{\infty}\end{array}$} & \multirow[b]{2}{*}{ 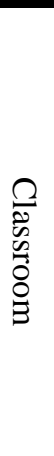 } & \multicolumn{4}{|c|}{ Characteristics } & \multicolumn{5}{|c|}{ October } \\
\hline & & 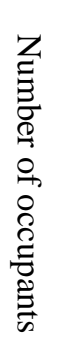 & 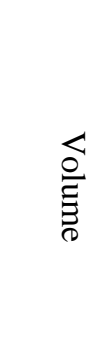 & 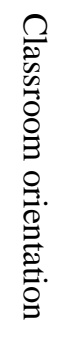 & 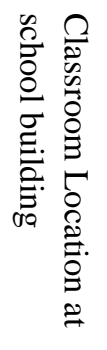 & 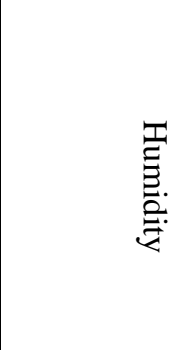 & 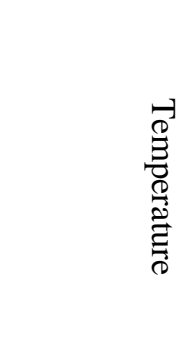 & 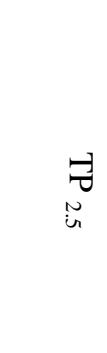 & 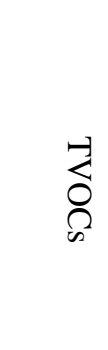 & రి \\
\hline \multirow{2}{*}{$D$} & $\Omega$ & $\vec{\sigma}$ & 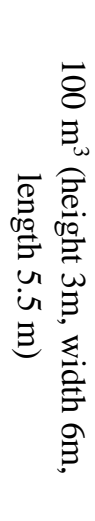 & $\begin{array}{l}\mathscr{\Omega} \\
\stackrel{\Xi}{\Xi}\end{array}$ & 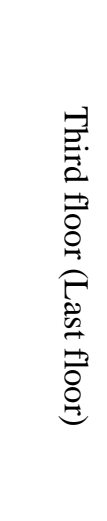 & 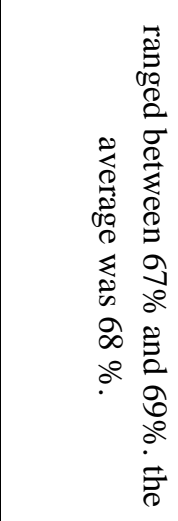 & 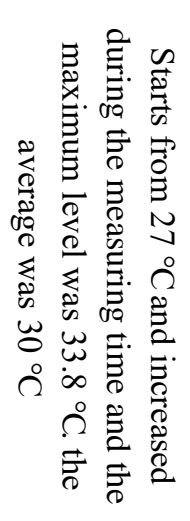 & 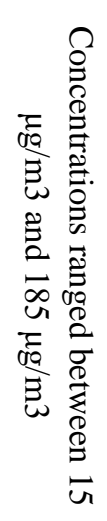 & 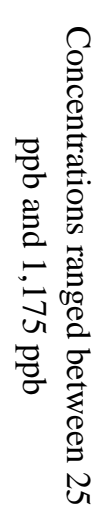 & 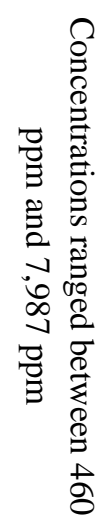 \\
\hline & N & $\stackrel{N}{\sim}$ & 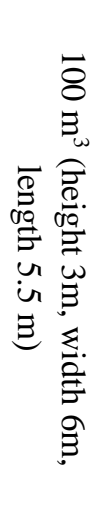 & 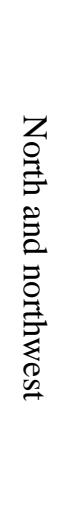 & 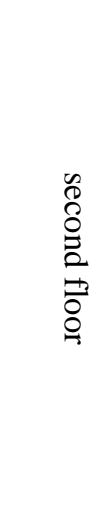 & 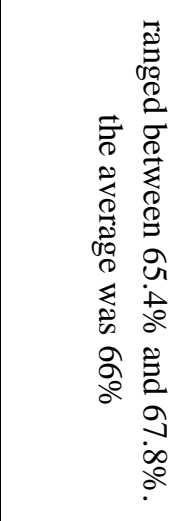 & 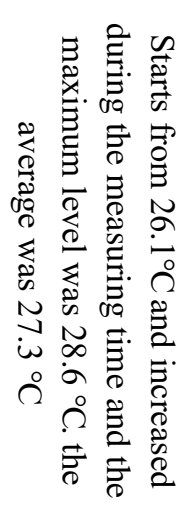 & 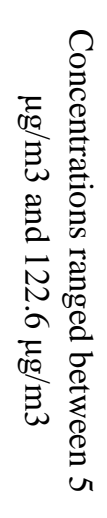 & 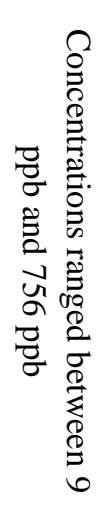 & 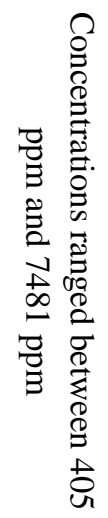 \\
\hline$\sigma$ & & 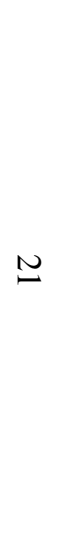 & 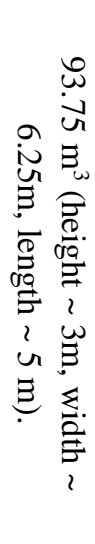 & $\begin{array}{l}\mathscr{\mathscr { \Omega }} \\
\stackrel{\Xi}{\Xi}\end{array}$ & 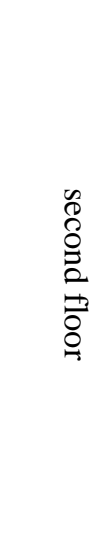 & 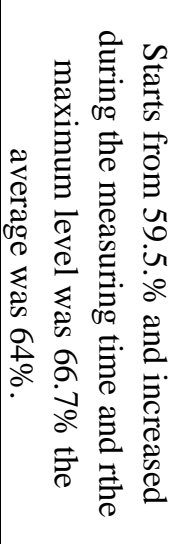 & 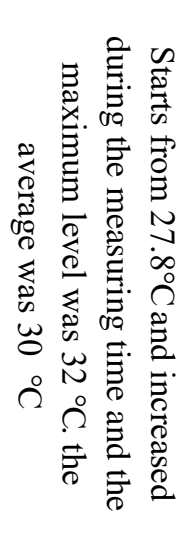 & 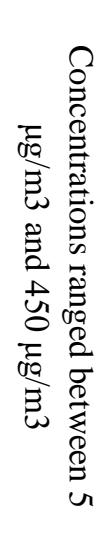 & 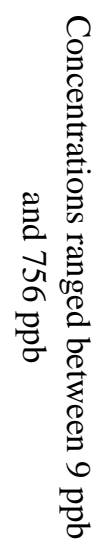 & 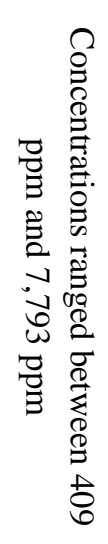 \\
\hline
\end{tabular}




\begin{tabular}{|c|c|c|c|c|c|c|c|c|c|c|}
\hline \multirow[b]{2}{*}{$\begin{array}{l}\tilde{n} \\
\frac{\hat{\sigma}}{0} \\
\frac{0}{n}\end{array}$} & \multirow[b]{2}{*}{ 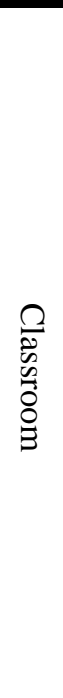 } & \multicolumn{4}{|c|}{ Characteristics } & \multicolumn{5}{|c|}{ October } \\
\hline & & 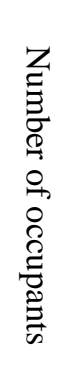 & 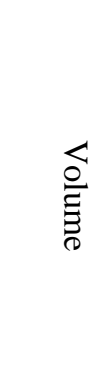 & 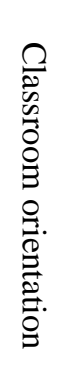 & 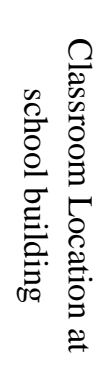 & : & 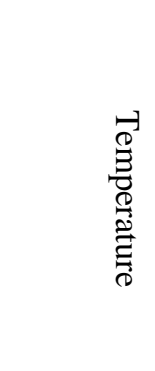 & $\begin{array}{l}\text { च } \\
\text { N }\end{array}$ & 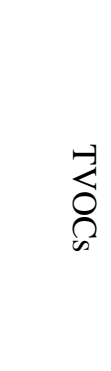 & ᄋి \\
\hline 2 & $\&$ & $\stackrel{N}{\sim}$ & 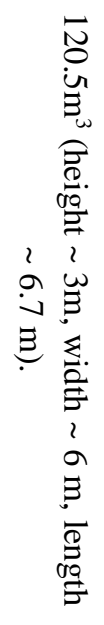 & 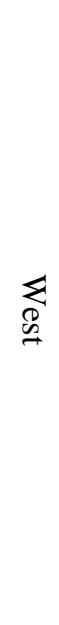 & $\begin{array}{l}0 \\
0 \\
0 \\
\vdots \\
\stackrel{0}{0} \\
\stackrel{0}{9}\end{array}$ & 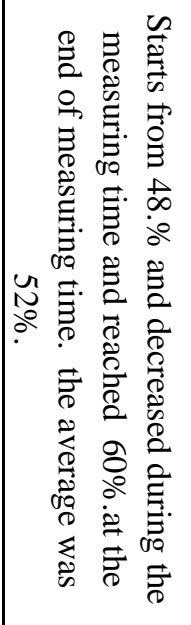 & 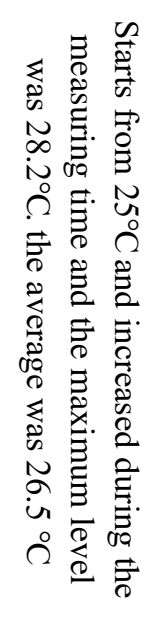 & 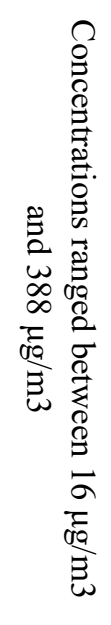 & 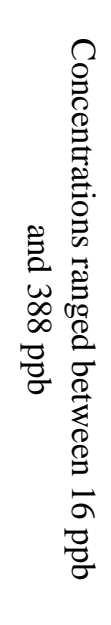 & 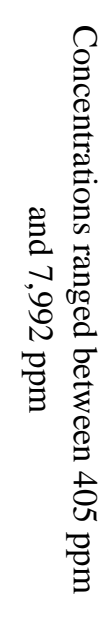 \\
\hline$\theta$ & O & $\sigma$ & 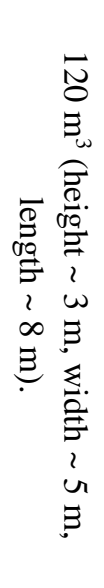 & $\begin{array}{l}\text { Z } \\
\stackrel{9}{=} \\
=\end{array}$ & $\begin{array}{l}T \\
\stackrel{7}{0} \\
\stackrel{0}{\oplus} \\
\stackrel{0}{0}\end{array}$ & 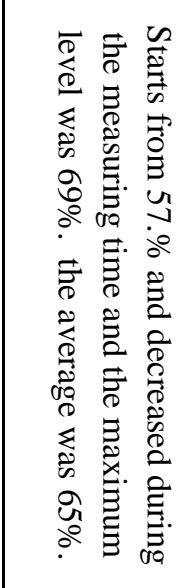 & 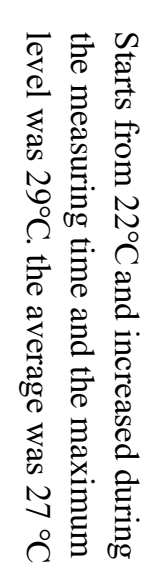 & 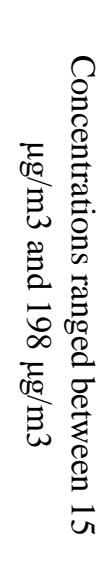 & 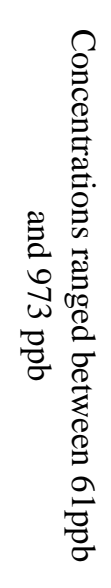 & 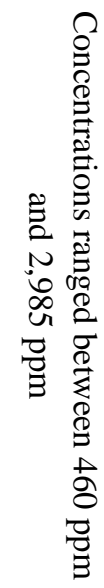 \\
\hline
\end{tabular}


Table 3: cold area measurements - Source: Authors

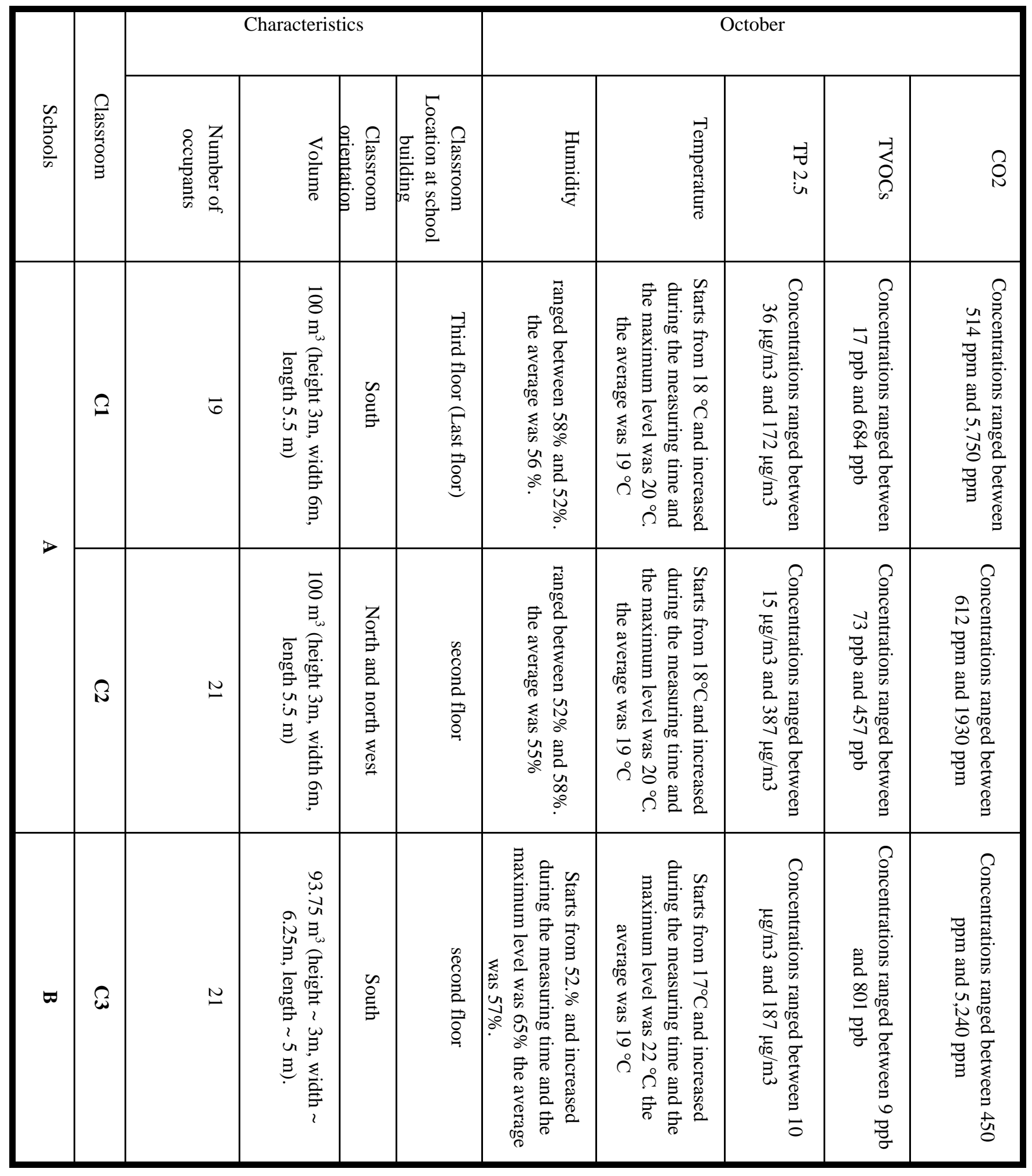




\begin{tabular}{|c|c|c|c|c|c|c|c|c|c|c|}
\hline \multirow{2}{*}{$\begin{array}{l}\tilde{\tilde{e}} \\
\frac{\hat{0}}{\omega} \\
\frac{0}{n}\end{array}$} & \multirow{2}{*}{$\begin{array}{l}\stackrel{0}{0} \\
\hat{0} \\
0 \\
0 \\
0 \\
0\end{array}$} & \multicolumn{4}{|c|}{ Characteristics } & \multicolumn{5}{|c|}{ October } \\
\hline & & 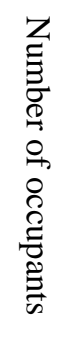 & 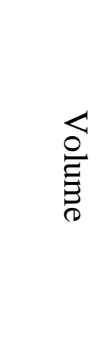 & 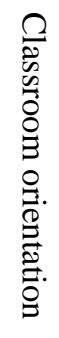 & 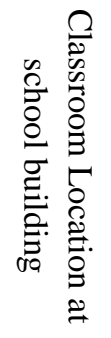 & 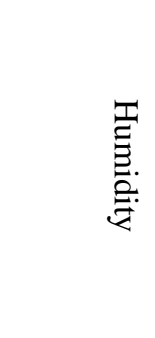 & 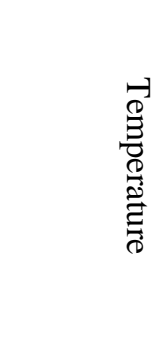 & $\begin{array}{l}\forall \\
\tilde{N} \\
\text { un }\end{array}$ & 定 & ᄋి \\
\hline 2 & $\AA$ & $\stackrel{N}{\sim}$ & 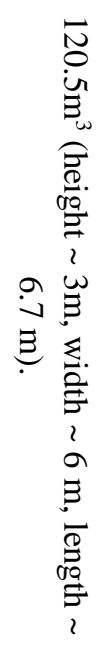 & 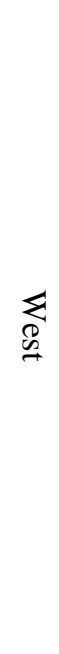 & $\begin{array}{l}\text { Q } \\
\stackrel{0}{0} \\
\Xi \\
0 \\
\stackrel{0}{0} \\
9\end{array}$ & 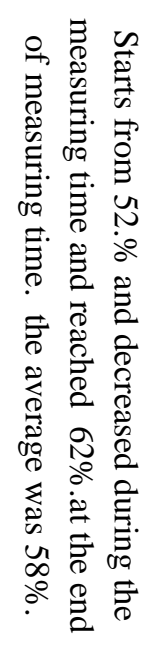 & 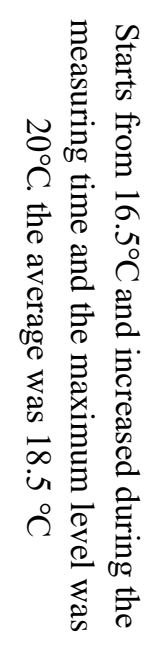 & 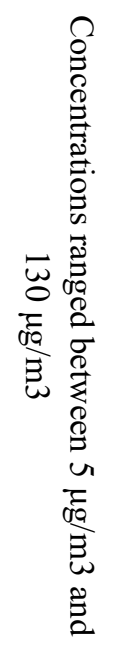 & 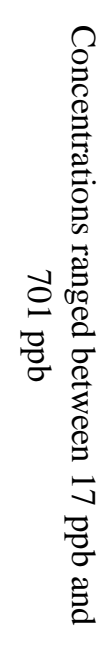 & 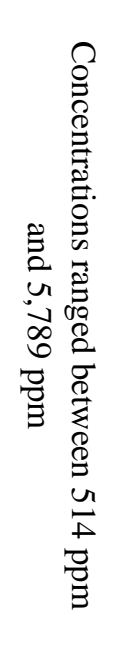 \\
\hline$\theta$ & O & $\varpi$ & 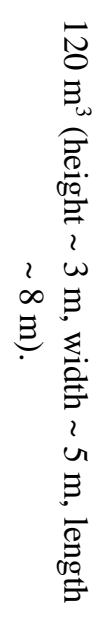 & $\begin{array}{l}Z \text { Z } \\
\stackrel{9}{=}\end{array}$ & $\begin{array}{l}T \\
\overrightarrow{0} \\
0 \\
\overrightarrow{0} \\
\stackrel{0}{0}\end{array}$ & 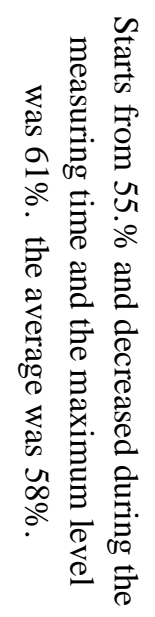 & 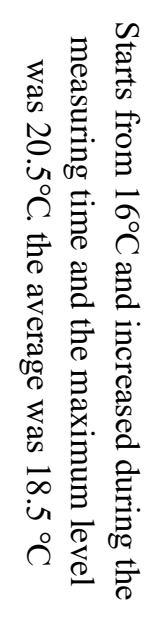 & 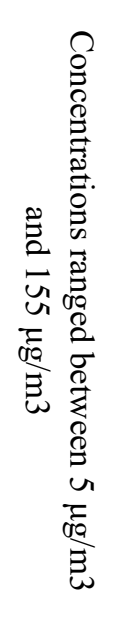 & 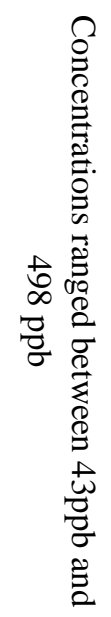 & 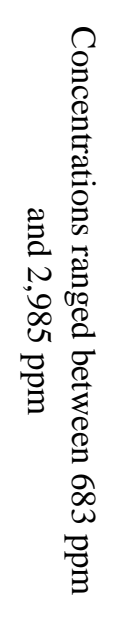 \\
\hline
\end{tabular}




\section{CONCLUSION}

This research study provided a means of measuring quantitative information for some of the main factors affecting the quality of natural ventilation in classrooms in primary schools in Egypt. Carbon Dioxide, Volatile organic compounds, Particulate matters.

The used device was developed locally by the researcher and some of his assistants, and it was calibrated by comparing with the readings of other devices. What distinguishes this device is the ease of reading several transactions at the same time; They are recognized as major influences on indoor air quality, and they are coefficients Carbon Dioxide, Volatile organic compounds, Particulate matters, Temperature and Humidity.

The measurements were made on four schools in downtown Cairo, where the areas of overcrowding, the degree of pollution is somewhat high. Table 4.

Configuring the design of buildings and classroom locations in the school building plays a vital role in reducing pollution limits and reducing indoor $\mathrm{CO} 2$ and VOC levels.

Levels of carbon dioxide and volatile organic compounds in all the schools studied were high enough to cause health or comfort problems.

It is observed that classrooms which oriented towards north and northwest direction (C2, C5) have the lowest concentration levels of $\mathrm{CO} 2$ and VOCs. Also, the 5 minutes break between the classes to change the teachers helps in reducing the concentration levels. Ventilation rates in all studied schools were insufficient to dilute indoor air contaminants. Polluted outdoor air also compromised the benefits of ventilation usage. $\mathrm{C} 2$ has openings at 3 walls of the classroom at the north and west direction (towards the prevailing wind direction) therefore, the $\mathrm{CO} 2$ concentration levels have fluctuated but at the acceptable ranges most of the measuring time, and the highest level was $1903 \mathrm{ppm}$. comparing this with $\mathrm{C} 1$ and $\mathrm{C} 4$, as $\mathrm{C} 1$ has openings at 3 walls but it is located at the southern part of the building therefore, it has poor air quality. $\mathrm{C} 4$ windows openings towards the west direction and has window and the door at the corridor which are closed during the teaching time that negatively affected the air flow and it caused the inadequate indoor air quality. Classrooms which were cleaned before start of the first-class session in morning with detergent had high indoor level of TVOCs. The CO2 concentration levels recorded inside the classrooms during operation time in the mild areas exceed values recommended in standards and are higher than those measured during cold areas.

During the break time the classroom's door was open, and no one was in the classroom, hence CO2 and TVOCs had a descending trend as it is expected. So, the break time helps in reducing the $\mathrm{CO} 2$ and TVOC levels. The students' belongings and students themselves may have contributed to the measured levels of TVOCs. It is observed that the dust PM2.5 levels have fluctuated, and the outdoor air pollution has an impact on the indoor concentration levels as the classrooms are naturally ventilated spaces.

\section{LIMITATION}

The major limitation of the study was that no Impact measurements include student's educational performance, students', and teachers' satisfaction survey. Not all types of school's designs configuration have been studied. 


\section{RECOMMENDATION}

Suitable recommendations are categorized for Ministry of education, schools' directors and the design consultants which play significant roles in enhancing the educational school buildings.

\subsection{Recommendations for Ministry of education and schools' directors}

1. It is essential for ministry of education to design schools which improve the educational and teaching needs of students and teachers, rather than continue implementing the same building prototypes regardless of the current functional needs of the educational environment.

2. It is necessary to understand the importance of air quality and its impact on health and educational performance of the students.

\subsection{Recommendations for Design Consultants}

Collaborating between the responsible stakeholders include the architects, teachers, students, and community members is important and necessary to improve the indoor air quality.

Some points observed by the authors

- Schools' building should be located away from the road, as it is observed that C5 which located at school D has a good air quality compared with the others.

- The orientation of the classrooms has a major effect in the adequacy of the indoor air quality, north and northwest direction are the best orientations.

- Rooms that are located at southern direction should be replaced with laboratories instead of being classrooms.

- Cleaning works should be done at least one hour before the start of the first class, or after the departure of students.

- Students number should be reasonable with the area of the classroom.

\section{ACKNOWLEDGMENT}

The authors would like to express their gratitude to Ismail S. Hasaballa, and Omar El Rawy for their help in developing the air quality monitoring device. Director of Misr El Qadima Educational Administration for his help in getting access to the schools used for this study. Assistance provided by schools' principals, and teachers are also gratefully acknowledged. 


\section{REFERENCES}

1. UNEP Yearbook 2014 emerging issues update Air Pollution: World's Worst Environmental Health Risk Available online at: https://www.who.int/news/item/27-09-2016-who-releasescountry-estimates-on-air-pollution-exposure-and-health-impact) Last accessed at 01/07/2021.EN 1338: Concrete Paving Blocks-Requirements and test methods. In British Standards (Vol. 3, Issue 1, pp. 1-33).

2. Ambient (outdoor) air quality and health: Available online at: https://www.who.int/en/news-room/fact sheets/detail/ambient-(outdoor)-air-qualityand-health Last accessed at 01/07/2021.

3. Cartieaux, E., Rzepka, M.A. and Cuny, D., (2011), Indoor Air Quality in Schools. Archives de Pediatrie (Page: 791-792).

4. Dorizas, P.V., Assimakopoulos, M. N. and Santamouris, M., (2015), A holistic approach for the assessment of the indoor environmental quality, student productivity, and energy consumption in primary schools. Environmental monitoring and assessment (Page: 5-6).

5. Egyptian Environment Affairs Agency, the Environmental Information and Monitoring Program (EEAA-EIMP), 2013, Population report for 2012-2013, Available online at: www.capmas.gov.eg and www.eeaa.gov.eg - Last accessed at 20/4/2019.

6. Almeida, R., De Freitas, V. P. and Delgado, J. M. (2015) Indoor Environmental Quality; School Buildings Rehabilitation.

7. Country cooperation strategy for WHO and Egypt 2014 Air Pollution: World's Worst Environmental Health Risk (Available online at: http://www.unep.org/yearbook/2014/PDF/chapt7.pdf) Last accessed at 01/07/2021.

8. IQAir most polluted cities 2019 (PM2.5) (Available online at: https://www.iqair.com/worldmost-polluted cities? continent $=\&$ country $=\&$ state $=\&$ page $=45 \&$ perPage $=50 \&$ cities $=)$ Last accessed at 01/07/2021.

9. United States Environmental Protection Agency EPA (Available online at: https://www.epa.gov/ghgemissions/overview-greenhouse-gases) Last accessed at 01/07/2021.

10. Canha, N.; Mandin, C.; Ramalho, O.;Wyart, G.; Ribéron, J.; Dassonville, C.; Hänninen, O.; Almeida, S.M.; Derbez, M., (2015), Assessment of ventilation and indoor air pollutants in nursery and elementary schools in France. Indoor Air, pp. 361-362.

11. United States Environmental Protection Agency EPA (Available online at: https://www.epa.gov/pm-pollution/particulate-matter-pm-basics) Last accessed at 01/07/2021.

12. United States Environmental Protection Agency EPA (Available online at: https://www.epa.gov/indoor-air-quality-iaq/volatile-organic-compounds-impact-indoor-airquality).

13. Zhouu Li. (2017) Arduuino environmental air monitoring system 